\title{
CONSTRUCTION PROCESSES OF ROOF STRUCTURES: SYSTEMATIC REVIEW
}

\section{PROCESSOS CONSTRUTIVOS DE ESTRUTURAS DE TELHADOS: UMA REVISÃO SISTEMÁTICA}

\section{T. L. PILZ ${ }^{1}$, M. SCHEUER ${ }^{1, *}$, M. M. C. MACENO ${ }^{1}$, T. GENARO ${ }^{1}$ and N. C. SOTSEK $^{1}$}

${ }^{1}$ Federal University of Paraná, Department of Production Engineering, Curitiba, Paraná, Brazil

${ }^{*}$ Corresponding author. Federal University of Paraná, Department of Production Engineering, Curitiba, Paraná, Brazil, Phone: +55 4799264551

e-mail address: scheuermayara@gmail.com (M. Scheuer).

\begin{tabular}{l} 
A R T I C L E I N F O \\
\hline Article history: \\
Received 2020-07-27 \\
Accepted 2020-10-20 \\
Available online 2020-10-20 \\
$k e y w$ or $d s$ \\
Constructive Processes \\
Systematic Review \\
Roofs \\
p a l a v r a s-ch a ve \\
Processos Construtivos \\
Revisão Sistemática \\
Telhados
\end{tabular}

\begin{abstract}
A B S T R A C T
Despite the fact that the construction industry in Brazil is traditionally recognized for the use of craft construction techniques, in the last few years, there has been a growth in the search for new materials, processes, and technologies for this segment. This is mainly due to the great environmental impact that this sector causes. Based on this context, this article aimed to map the constructive processes of existing roofs in the literature, to raise its advantages, disadvantages and previous cases. To achieve this aim, the systematic review method based on three phases - research questions, selection of documents and classification of selected documents, and the $5 \mathrm{~W} 2 \mathrm{H}$ quality tool were used. Thus, this research could contribute to the literature on this topic, as well as encourage the idealization of new ideas of roof construction processes.
\end{abstract}

\section{R E S U M O}

Apesar da indústria da construção civil no Brasil ser tradicionalmente reconhecida pelo uso de técnicas artesanais de construção, percebeu-se nos últimos anos um crescimento na busca de novos materiais, processos e tecnologias para este seguimento. Isso se deve, principalmente, ao grande impacto ambiental que este setor causa. Dessa forma, esse artigo teve como objetivo mapear os processos construtivos de telhados existentes na literatura, levantar suas vantagens, desvantagens e possíveis aplicações. Para alcançar a esse objetivo utilizou-se o método de revisão sistemática baseado em três fases - perguntas de pesquisa, seleção dos artigos e classificação dos artigos selecionados - e a ferramenta de qualidade $5 \mathrm{~W} 2 \mathrm{H}$. Com isso, espera-se com essa pesquisa contribuir com a literatura sobre esse assunto, como também, incentivar a idealização de novas ideias de processos construtivos de telhados. 


\section{INTRODUCTION}

The construction industry in Brazil is, historically, recognized for the use of craft construction techniques. In the last decade, however, there has been a wave of growth and the possibility of innovation in the sector, due to the availability of credit in the market (FLACH, 2012). The search for alternative construction processes is justified by the high impact on the environment generated by traditional Civil Construction, due to the large use of raw materials, energy, water and the generation of waste in their construction processes (VALPORTO et al., 2016).

Sanyé-Mengual et al. (2014) cites dematerialization as a strategy in its methodology for implementing Eco design in companies. The author mentions that the materials of a product or process can be optimized in different ways, the reduction of the amount of resources being one of them. At a time when some techniques are already widespread, such as lean tools, it is essential to find new ways to increase efficiency in organizations (ALMEIDA et al., 2012).

Flach (2012) mentions that, traditionally, the roofs of buildings in Brazil follow the characteristics of Portuguese colonial roofs, using discontinuous sawn wood structures. However, there are other materials and construction systems that can be an alternative to traditional systems. Given this, it is important to look for roof construction processes, which have better performance and less environmental impacts. However, before considering something new, it is essential to seek information about existing processes, for better solutions and lower risks.

In this context, this article aimed to identify the existing production processes in the construction of roofs, their field of application, as well as their advantages and disadvantages, using for this purpose the method of systematic literature review.

\section{METHOD}

The method used for the systematic literature review was the method proposed by Gohr et al. (2013). This is based on three phases, which were divided into stages that represent the steps to be followed to survey the materials in the literature. Figure 1 shows the steps of this method. The details of each phase are presented in topics 2.1 to 2.3 .

\begin{tabular}{|c|c|c|}
\hline $\begin{array}{l}\text { Research } \\
\text { questions }\end{array}$ & $\begin{array}{l}\text { Selection of } \\
\text { the documents }\end{array}$ & $\begin{array}{l}\text { Classification } \\
\text { of the selected } \\
\text { documents }\end{array}$ \\
\hline $\begin{array}{l}\text { - Delimitation of the } \\
\text { topic to be researched } \\
\text {-Definition of keywords } \\
\text { and combinations } \\
\text { - Definition of exclusion } \\
\text { keywords } \\
\text { - Delimitation of the } \\
\text { period of publication of } \\
\text { documents } \\
\text { - Database selection }\end{array}$ & $\begin{array}{l}\text { - Search for articles } \\
\text { according to the criteria } \\
\text { established in the } \\
\text { previous phase } \\
\text { - Inclusion and } \\
\text { exclusion criteria }\end{array}$ & $\begin{array}{l}\text { - The documents are } \\
\text { organized according to } \\
\text { the criteria and } \\
\text { relevance established } \\
\text { by the researcher }\end{array}$ \\
\hline
\end{tabular}

Figure 1 - Stages of the systematic review method.

\subsection{Research questions}

This is the step that contains the definition of the main parameters about the research. To define the topic of the bibliographic survey and the period of such references, the questions "what?" are asked and "when?" at the beginning of the literature review. Thus, the theme to which the bibliographic survey will be made and the delimitation of the period that such materials were produced are defined. In answering these questions, it was defined as the theme of this systematic review" Variations in production processes in roof construction", with the time limitation of references found of 10 years.

Gohr et al. (2013) mentions that after the delimitation of the theme, the keywords are defined, which identify the theme being researched, in this research, you can perform combinations of keywords and also exclusions. In international bases can be used boolean operators, such as and, or and not. Exclusion keywords are combined by the use of the delete operator (not). When it comes to only combinations of keywords, the inclusion operators (or and and) can be used. On bases that contain national documents such as Google Scholar, the combination of keywords can be done with the use of quotation marks (""), if there is a need for the words together, or by the use of the Boolean operator "or" for combination of searches. The deletion is done by using the hyphen in front of the word.

It is important to emphasize the importance of choosing the database for the research. Google Scholar, SCielo, Web of Science, Science Direct or Scopus are examples of some databases that can be used.

\subsection{Selection of the documents}

In this phase, the documents found were surveyed and qualified. The first search consisted of generic words on the main subject of the research, to know a general sample of materials to be worked on.

Then it was necessary to define the exclusion criteria of the material found, in order to have knowledge of the sample for use in the research. The type of document was not defined as an exclusion criterion, therefore, articles published in journals and congresses, dissertations, theses, book chapters and course completion papers were considered.

In the first stage of this phase, the keywords in the title, abstract and/or keywords of the material were. At this time, Boolean operators were used to combine or exclude keywords.

The second step consisted of filtering the materials found, the first filtering was based on the reading of the titles of the materials for alignment with the theme. Thus, in the second filtering abstracts of the remaining materials were read, qualifying those that fit the researched theme.

\subsection{Classification of the selected documents}

At this stage of the research, it was possible to organize the articles, so that a classification could be made of those that stand out and can be considered for research conclusions. Therefore, it is perceived that the objective of this phase is to collaborate for an ordered study, which follows a pattern that will vary according to the need of the research and what he prioritizes as a focus for developing his work Gohr et al. (2013).

The classification of the materials can be done in two ways, the first being to sort the articles according to their 
academic relevance, defined according to an analysis of the citations and later according to the need of who is researching. Or, the second form of classification can be made in general, with the extraction of information such as title, year of publication, authors, journals, number of citations, JCR and Qualis (CAPES), or specifically on the content of the article, with the extraction of keywords, objective, if the article is theoretical/empirical, method used, sector of application (empirical research), concepts adopted and results achieved (GOHR et al., 2013).

Another form of data extraction is the use of the $5 \mathrm{~W} 2 \mathrm{H}$ tool, as used Lisbôa et al. 2012. This quality tool quickly provides the fundamental elements of a project. This method is based on the answer to the questions in Table 1.

Table 1 - 5W2H Tool.

\begin{tabular}{|c|c|c|}
\hline 5W2H & Questions & Answers \\
\hline WHO & $\begin{array}{l}\text { Who developed the } \\
\text { study? }\end{array}$ & Authors \\
\hline WHERE & $\begin{array}{l}\text { Where was the } \\
\text { research done? } \\
\text { Where are the } \\
\text { authors from? }\end{array}$ & Location \\
\hline WHEN & $\begin{array}{c}\text { Year of publication? } \\
\text { Study duration? }\end{array}$ & $\begin{array}{c}\text { Year of } \\
\text { publication, } \\
\text { Experiment time }\end{array}$ \\
\hline WHY & $\begin{array}{c}\text { What was the study } \\
\text { problem/justification } \\
\text { that motivated the } \\
\text { study? }\end{array}$ & Motivation/Interest \\
\hline HOW & $\begin{array}{l}\text { How was the study } \\
\text { done (step by step)? } \\
\text { How was the } \\
\text { experiment carried } \\
\text { out (steps)? How is } \\
\text { the structured made? }\end{array}$ & $\begin{array}{l}\text { Structure step by } \\
\text { step }\end{array}$ \\
\hline
\end{tabular}

It is important to emphasize that in this step you can use Excel spreadsheets to better organize and view the information of the articles. In this article, the 5W2 $\mathrm{H}$ tool was applied to those articles that were considered more relevant to achieve the proposed objective.

\section{RESULTS AND DISCUSSION}

Based on the Systematic Literature Review method proposed by Gohr et al. (2013), the results of this study were elaborated being presented in this chapter (3.1 to 3.3). These topics refer to the Research Questions, Selection of articles, and Classification of them, respectively.

\subsection{Research Questions}

As mentioned in topic 2.1, the objective of this research was to find "Variations in production processes in the construction of roofs", with the reference timeline of 10-year. To achieve this objective, the keywords according to Table 2 and their variations were used to search for materials on the topic.

Considering the importance of databases, the Systematic Literature Review was carried out in July 2018, using the following databases: Google Scholar and Science Direct. The search was made in Portuguese in the Google Scholar database and in English in the Science Direct database.

Table 2 - Portuguese and English keywords used in the research.

Keywords
Processos construtivos de telhados
Inovações em telhados
Method of building the house roof
Roofing construction
New roofing construction
Construction of slabs

\subsection{Selection of the documents}

In the beginning, the search was made with the most generic keywords, so that it was possible to have a brief knowledge of the sample size without restrictions or combinations of keywords. In this moment was found the large number of materials related to green roof construction processes. However, as mentioned in the introduction to this article, this review focused on processes that have greater dematerialization, that is, processes that require less raw material and resources for its execution. Therefore, the filtering consisted of the exclusion of these terms. Thus, the combination and restrictions in the search for the materials were carried out. Table 3 illustrates the impact of the first filter on the size of the samples found.

Table 3 - Impact of the first combination of the keywords.

\begin{tabular}{|ccc|}
\hline Keywords & $\begin{array}{c}\text { Science } \\
\text { Direct }\end{array}$ & $\begin{array}{c}\text { Google } \\
\text { Scholar }\end{array}$ \\
\hline $\begin{array}{l}\text { Processos construtivos de telhados } \\
\text { Processos construtivos de telhados }\end{array}$ & 1699 & 10100 \\
- "telhado verde" AND inovação & 345 & 2060 \\
\hline
\end{tabular}

For the Selection of articles, filtering based on the combination of keywords "variações", "inovações", "processos construtivos", and "telhados", excluding "telhado verde" and "telhados verdes". After the combinations, a sample of 195 materials on the subject was found, 167 on Google Scholar and 28 on Science Direct.

Given the selecting the sample, the first and second steps proposed by Gohr et al. (2013), that is, to read the title, keywords, abstracts, and to eliminate repeated files or without access. At this step, it was noticed that most of the materials found did not have roof structures as their main focus, but rather the construction processes of buildings. However, within the materials it was noted that the subject was recurrent. Thus, further filtering was necessary to obtain a more realistic sample to achieve the objective of this article. For this, the abstract of the materials found was read.

Figure 2 shows the steps and results of the filtering, being that it obtained a sample of 51 materials. From this sample, the selected articles were organized.

\subsection{Classification of the selected documents}

For organization and classification in this step, Gohr et al. (2013) suggests that the sample files be organized in a table according to Table 1, in topic 2.3. The last sample was organized according to the Table proposed by the author, but some changes were made. Then, the following topics were used: title, year of publication, author, keywords, and Construction System. This step was important to identify the variations of the 
production systems, as shown in Table 4. It is important to note that Table 4 illustrates only 5 of the 51 materials found, just as a way of better illustrating the organization of these files.

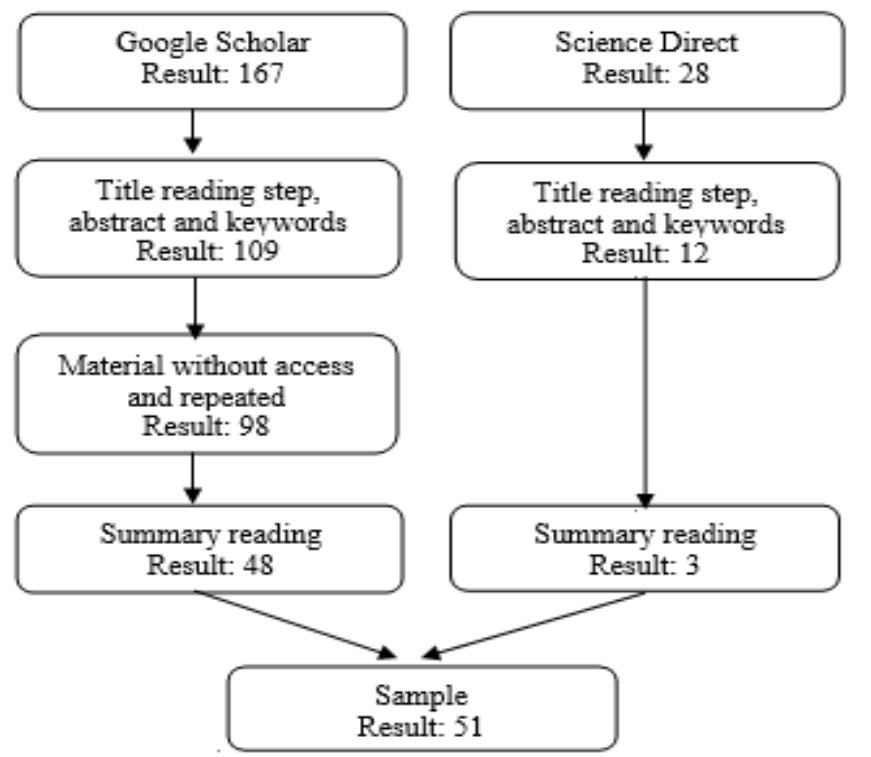

Figure 2 - Sample documents after applying the exclusion criteria.

According to the content analysis, it was observed that the variations in the construction process were directly related to the material used for the roof. Thus, with the aid of Table 4, the material found was classified according to the materials used, which are wood, reinforced concrete, steel, and other materials.

Table 5 shows the number of studies found concerning the raw material applied in the construction process. It is also noteworthy that some materials have different variations of raw material, such as roofs made of bamboo and straw. Consequently, they do not fall into a single category, such as wood, steel or reinforced concrete, and are therefore classified as "other materials". Such classification was disregarded in the analysis of construction processes, as it was identified that these processes have the same construction systems as the other classifications. Therefore, the analysis was performed based on materials classified as wood, steel, and reinforced concrete. In addition, it is noted that the total number of articles results in a larger number than the sample obtained. This is justified by the fact that some articles describe more than one material and process.

Table 5 - Classification of materials according to raw material.

$\begin{array}{cc}\text { Material } & \text { Number of articles } \\ \text { Wood } & 24 \\ \text { Reinforced Concrete } & 11 \\ \text { Steel } & 21 \\ \text { Other materials } & 5 \\ \text { Total } & 61\end{array}$

After the classification of the adopted materials, it was established as priority criteria, the selection of studies that most specified and detailed the roof construction processes. Then, the diagonal reading of the 51 studies was carried out in order to obtain the expected result. The result obtained with the diagonal reading corresponded to the selection of four documents that, therefore, were read in full (Figure 3).

For data analysis, the final sample of documents was read and understood and with the aid of the quality tool $5 \mathrm{~W} 2 \mathrm{H}$, mentioned in item 2.3 of this article, the fundamental elements of the materials considered as priorities by the authors were extracted. For this review, the tool was used only for one $\mathrm{H}$ ("How"). This was established due to insufficient information to answer the questions regarding the cost of construction processes. The result obtained using this tool is shown in APPENDIX A.

Based on the analysis of the fundamental information using the quality tool, it was possible to identify the variations of the construction processes found and their details. As previously mentioned, such processes differ according to the material of the roof structure, so they were classified and arranged according to Figure 3.

\begin{tabular}{|c|c|c|}
\hline Wood structure & $\begin{array}{c}\text { Reinforced Concrete } \\
\text { Structure }\end{array}$ & Steel structure \\
\hline $\begin{array}{l}\text { Prefabricated wood } \\
\text { Continuous Wood Frame } \\
\text { - panels and punctured }\end{array}$ & $\begin{array}{l}\text { Continuous precast } \\
\text { Discontinuous precast } \\
\text { Precast slabs } \\
\text { Lattice slabs } \\
\text { Panel Slabs } \\
\text { Massive Slabs } \\
\text { Continuous molded on site } \\
\text { Discontinuous molded on site }\end{array}$ & $\begin{array}{l}\text { Continuous Light Steel } \\
\text { Framing } \\
\text { Discontinuous Light Steel } \\
\text { Framing }\end{array}$ \\
\hline
\end{tabular}

Figure 3 - Construction processes by roof structure material.

Although the raw material is different, it was noted that the processes and dispositions of the materials do not differ significantly from each other. However, as Flach (2012) and Dermine (2013) mention, each process has advantages and disadvantages and a recommended application. This information is structured in Table 6.

It can be seen that despite the need for steel treatment, the Light Steel Framing structure is the only structure that is $100 \%$ recyclable. Besides that, it was also remarked that the wooden structures have a higher cost in relation to the costs of the other structures, however, they are the oldest and known by the market.

Also, despite being disregarded when searching for articles, it is interesting to mention the existence of the green roof as a construction process for roofs. Some of the advantages of this type of coverage, according to Alberto et al. (2012), may be the possibility of urban agriculture, energy efficiency, reduction of heat islands, flood control, urban aesthetics, air quality, increase in the useful area and the appreciation of properties. However, it requires specialized labor, has a high initial cost, and can generate infiltrations if it is built in the wrong way. 
Table 4 - Illustration of the documents organization table.

\begin{tabular}{|c|c|c|c|c|}
\hline Title & Year & Authors & Keywords & $\begin{array}{l}\text { Construction } \\
\text { system }\end{array}$ \\
\hline $\begin{array}{l}\text { Estudo de processos construtivos modulares } \\
\text { do ponto de vista da sustentabilidade. }\end{array}$ & 2016 & $\begin{array}{l}\text { Felipe Ribeiro } \\
\text { Amorim }\end{array}$ & $\begin{array}{l}\text { Processos construtivos, } \\
\text { sustentabilidade, modulação. }\end{array}$ & $\begin{array}{l}\text { LSF; concreto pré- } \\
\text { moldado; painéis } \\
\text { pré-fabricados }\end{array}$ \\
\hline $\begin{array}{c}\text { Otimização de processos construtivos através } \\
\text { da inserção de novas tecnologias na indústria } \\
\text { da Construção Civil: Vantagens da aplicação } \\
\text { do sistema Light Steel Framing (LSF) em } \\
\text { residências. }\end{array}$ & 2013 & $\begin{array}{l}\text { João Paulo } \\
\text { Beato de } \\
\text { Oliveira }\end{array}$ & $\begin{array}{l}\text { Sistemas construtivos, Light } \\
\text { Steel Framing, Sistema } \\
\text { Convencional }\end{array}$ & $\begin{array}{l}\text { Light Steel } \\
\text { Framing; } \\
\text { convencional }\end{array}$ \\
\hline $\begin{array}{c}\text { Método para análise de desempenho no } \\
\text { critério funcionalidade e acessibilidade para } \\
\text { coberturas de edificações segundo a NBR } \\
15.575 / 2008\end{array}$ & 2012 & $\begin{array}{c}\text { Gabriel Ruiz } \\
\text { de Oliveira }\end{array}$ & $\begin{array}{l}\text { Desempenho de edificações, } \\
\text { NBR 15.575. Coberturas, } \\
\text { Construção em madeira }\end{array}$ & $\begin{array}{c}\text { Estrutura } \\
\text { convencional }\end{array}$ \\
\hline $\begin{array}{l}\text { Comportamento mecânico de treliças de } \\
\text { madeira com ligações por chapas de dentes } \\
\text { estampados. }\end{array}$ & 2014 & $\begin{array}{l}\text { Rapi Kazuo } \\
\text { Nagaoka }\end{array}$ & $\begin{array}{l}\text { Chapas com Dentes } \\
\text { Estampados, Est. } \\
\text { industrializadas. Treliças de } \\
\text { madeira. Ligações } \\
\text { semirrígidas. }\end{array}$ & Treliças \\
\hline $\begin{array}{l}\text { Proposta de conector para ensaios de } \\
\text { ligações CDE submetidas à tração } \\
\text { perpendicular as fibras em madeira de pinus }\end{array}$ & 2011 & $\begin{array}{l}\text { Rodrigo } \\
\text { Batista Pereira }\end{array}$ & $\begin{array}{l}\text { Chapa com dentes estampados. } \\
\text { Ligações. Estrutura de } \\
\text { Madeira. Ensaios. Resistência. }\end{array}$ & Treliças \\
\hline
\end{tabular}

Table 6 - Advantages and disadvantages of production processes.

\section{Material} Structure Advantages Prefabricated

Continuous Industrial product, greater fire

Wood Wood Frame - resistance and versatility of projects panels

Punctured

Continuous precast

Discontinuous precast

Continuous molded on site

Discontinuous

Reinforced molded on site Concrete

Precast slabs

Lattice slabs

Panel Slabs

Greater resistance

Massive Slabs
Quick assembly, elaboration of the previous design of parts and connections and reforestation wood can be used

Manual assembly, lightness of the parts, flexibility of design adequacy, market acceptance and wood reduction
Greater knowledge of users when related to slabs specialized equipment Use of more resistant materials, faster execution and greater availability of suppliers

Possibility of attic and prior design

Replacement of high cost and large section wooden parts with lower cost concrete parts

Compared to solid slabs, they have a lower cost (due to the fact that they already have their own frame) Uphold large spans

Higher expense (except when Disadvantages

Exact supports and dimensions according to the project, low flexibility; higher cost compared to other

Lack of flexibility, higher cost compared to traditional structure and requires

Need for qualified labor and horizontal slab

High self-weight and difficulty in transport

Possible corrosion of the compared to massive ones); finishing required High cost

Higher costs compared to precast slabs Application

Buildings with small or large spans

Small or large spans

Suitable when there is a horizontal upper slab

Industrial buildings with large spans

Can be used in small or large spans

$$
\text { weight compared to }
$$

discontinuous wooden or steel structures

Higher cost in relation to the batch and difficulty when it is inclined

Possibility of corrosion of the reinforcement

Residential

buildings with small spans

Used in small spans

Small and medium spans and can be spaced up to $1.2 \mathrm{~m}$ Suitable for large spans

Large spans and buildings that require no finishing Must be arranged at $0.8 \mathrm{~m}$ 


\section{CONCLUSION}

Throughout this research, it was noticed that, although the sample of materials initially found in the literature was large, these materials described all stages of the construction processes of construction. Although coverage is one of those steps, in most documents, this was not treated as the main focus. Thus, it was necessary to have more detailed filtering on the material found, and more comprehensive attention to those who had detailed processes.

After all the steps, it was possible to identify the variations and possible innovations of construction processes found in the literature, which can be divided as follows:

- Prefabricated wooden structure; continuous with panels; punctured;

- Precast reinforced concrete structure (continuous or discontinuous); precast slabs, latticed, panel or massive; molded on site (continuous or discontinuous);

- Light Steel Framing (continuous or discontinuous).

Although the green roof is known as an ecological roof, its construction process requires a lot of material for the initial construction, going against the dismantling strategy mentioned in the introduction of this research. When compared to each other, the structures identified are very similar in their construction processes, but each has its own peculiarity of raw material, equipment, labor, and execution.

Analyzing the advantages and disadvantages mentioned in item 3.3 of this article, Light Steel Framing was considered as the most appropriate construction process in reducing environmental impacts, mainly due to the reduction of natural resources such as water and electricity and the low amount of waste generated on site. In addition, despite being an expensive process when compared to those mentioned in this research, its installation is quick, reducing the time needed for installation and, consequently, the cost of workers on the construction site.

Finally, the main contribution of this research was related to the generation of knowledge of the current construction processes, their advantages, and disadvantages. As a result, it is expected that the content produced in this article can facilitate and induce the generation of new ideas for the construction of roofs, thus enabling a new approach for future study.

\section{R E F E R E N C E S}

ALBERTO, E.Z.; RECCHIA, F.M.; PANEDO, S.R.M.; PALETTA, F.C. Estudo do telhado verde nas construçõessustentáveis. São Paulo, SP. 2012.

AMORIM, F.R. Estudo de processos construtivos modulares do ponto de vista da sustentabilidade. Rio de Janeiro, RJ. 2016

AVILA, L.; TEIXEIRA, L.; ALMEIDA, P. Desmaterialização de processos com recurso a tecnologias open-source numa instituição de ensino superior. Portugal. 2012

DETERMINE, M.L.B. Comparação entre lajes pré-fabricadas, treliçadas maciças e painéis na contrução civil. Lages, SC. 2013.

FLACH, R.S. Estruturas para telhados: Análise técnica de soluções. Porto Alegre. 2012
GASPAR, P.D. Construção de edifícios de habitação em light steel framing: Alternativa viavel à construção tradicional. Porto. 2013.

GOHR, C.F.; SANTOS, L.C.; GONÇALVES. A.M.C.; PINTO, N.O. Um método para a revisão sistemática da literatura em pesquisa de engenharia de produção.Salvador, BA. 2013.

LEITNER, D.S. Avaliação pós-ocupação em edificações: Uma revisão sistemática de suas características.Curitiba, PR. 2017.

LISBÔA, M.G.P., GODOY, L.P. Aplicação do método 5W2H no processo produtivo do produto: a joia. Florianópolis, SC. 2012.

VALPORTO, M.S., AZEVEDO, P.S. Gestão do design na identificação dos fatores de impacto ambientais da contrução civil. Rio de Janeiro, RJ. 2016.

NAGAOKA, R.K. Comportamento mecânico de treliças de madeira com ligações por chapas de dentes estampados. Campo Mourão, PR. 2014

OLIVEIRA, G.R. Método para análise de desempenho no critério funcionalidade e acessibilidade dos sistemas em madeira para coberturas de edificações segundo a NBR 15.575/2008. Curitiba, PR. 2012.

OLIVEIRA, J. P. B.; Otimização de processos construtivos através da inserção de novas tecnologias na indústria da construção civil. Pato Branco, PR. 2013.

PEREIRA, R.B. Proposta de conector para ensaios de ligações CDE submetidas à tração perpendiculas as fibras em madeira de pinos. Itapeva, SP. 2011.

SANYÉ-MENGUAL, E., LOZANO, R. G., FARRENY, R. OLIVER-SOLÀ, J., GASOL, C.M. RIERADEVALL, $\mathrm{J}$. Introduction to the eco-design methodology and the role of Product Carbon Footprint. Cabrils, Barna. 2014. 


\section{APPENDIX A}

\begin{tabular}{|c|c|c|c|c|}
\hline 5W1H & $\begin{array}{l}\text { Comparison between prefabricated, } \\
\text { latticed, solid slabs and panels in } \\
\text { civil construction }\end{array}$ & $\begin{array}{l}\text { Wood frame systems for wood } \\
\text { houses }\end{array}$ & $\begin{array}{l}\text { Light Steel Framing residential } \\
\text { buildings construction }\end{array}$ & $\begin{array}{c}\text { Roof structure: Technical analysis of } \\
\text { solutions }\end{array}$ \\
\hline WHO & DEMERTINE, Matheus. L. B. & MOLINA, Julio C.; JUNIOR,Carlito C. & GASPAR, André P. & FLACH. Rafael S. \\
\hline WHERE & Lages, Santa Catarina - Brazil & Londrina, Paraná - Brazil & Porto - Portugal & Porto Alegre, Rio Grande do Sul - Brazil \\
\hline WHEN & 2013 & 2010 & 2013 & 2012 \\
\hline \multirow[t]{2}{*}{ WHAT } & $\begin{array}{l}\text { Define the ideal type of slab to be used } \\
\text { in a construction to ensure safety, save } \\
\text { assembly time }\end{array}$ & $\begin{array}{l}\text { Wood frame systems characteristics: } \\
\text { implantation difficulties; contribution } \\
\text { to national literature in the subject }\end{array}$ & $\begin{array}{l}\text { Present a new way of building and try } \\
\text { to comprehend how Light Steel } \\
\text { Framing can change the construction } \\
\text { paradigm in Portugal. }\end{array}$ & $\begin{array}{l}\text { Applications for the presented roof } \\
\text { structures, with advantages and } \\
\text { disadvantages. Identification and technical } \\
\text { description of technical solutions for roof } \\
\text { structures }\end{array}$ \\
\hline & $\begin{array}{l}\text { Prefabricated slab; Trellis; panel; } \\
\text { massive }\end{array}$ & Wood Frame structure & Light Steel Framing structure & $\begin{array}{l}\text { Wood structure; reinforced concrete; steel } \\
\text { structure }\end{array}$ \\
\hline WHY & $\begin{array}{l}\text { Due to the large amount of labor, time } \\
\text { and waste of materials in the process of } \\
\text { ribbed slabs molded in loco in } \\
\text { constructions, it is necessary to find } \\
\text { innovations }\end{array}$ & $\begin{array}{c}\text { The wood frame system for house } \\
\text { constructions is very interesting, as it is } \\
\text { a lightweight system, with numerous } \\
\text { advantages. }\end{array}$ & $\begin{array}{l}\text { Despite its evolution, traditional } \\
\text { construction processes remain the same } \\
\text { in their basic design, being inefficient } \\
\text { as for the rationalization of } \\
\text { construction materials. }\end{array}$ & $\begin{array}{l}\text { Other solutions for roof structures, more } \\
\text { suitable and efficient for certain projects } \\
\text { than the traditional discontinuous wooden } \\
\text { structure must be studied }\end{array}$ \\
\hline HOW & $\begin{array}{l}\text { Pre-molded slab: Joists assembled on } \\
\text { the frame, followed by a filler fitting } \\
\text { on the entire horizontal joist } \\
\text { arrangement. After the assembly, } \\
\text { shoring is done, when the concrete } \\
\text { reaches the resistance, the shores can } \\
\text { be removed. Distance between each } \\
\text { joist: } 40 \mathrm{~cm} \text { (axis to axis). }\end{array}$ & $\begin{array}{l}\text { On the walls of the last floor are } \\
\text { positioned industrialized wooden } \\
\text { trusses with connectors of the stamped } \\
\text { tooth plate type. Depending on the type } \\
\text { of roof tile used, the spacing between } \\
\text { the trusses can vary between } 60 \mathrm{~cm} \text { and } \\
120 \mathrm{~cm} \text {. The lower bane of the trusses } \\
\text { is not always the reference level for the } \\
\text { application of the lining. }\end{array}$ & $\begin{array}{l}\text { They follow the principles of profiling. } \\
\text { Floor beams use Ue section profiles, } \\
\text { with a } 200 \text { or } 250 \mathrm{~mm} \text { section. The } \\
\text { floor profiles are kept in line with the } \\
\text { wall beams. Floor: Slabs composed of } \\
\text { horizontal beams, it is necessary to } \\
\text { create a horizontal platform on which } \\
\text { the interior walls will rest. Roof: Two } \\
\text { types of solutions are used, flat roofs or } \\
\text { inclined roofs. }\end{array}$ & $\begin{array}{l}\text { Wooden structure: 1. Main Structure: } \\
\text { Bracing: Formed by a main system of } \\
\text { structural elements, arranged with their } \\
\text { greatest rigidity in parallel planes. } \\
\text { Supports: Roof trusses must be supported } \\
\text { on cushions, lashing straps or frechals. } 2 \text {. } \\
\text { Secondary Structure: Purlins: horizontal } \\
\text { beam, parallel to the eaves and supported } \\
\text { by scissors, supports the rafters. Rafters: } \\
\text { Nailed on purlins. Slats: Nailed in the } \\
\text { rafters, their spacing depends on the roof } \\
\text { tile. }\end{array}$ \\
\hline
\end{tabular}


Comparison between prefabricated, latticed, solid slabs and panels in civil construction

Trussed slabs: The frame of the joist is trussed and these will have a

rectangular cross section. The joists are assembled in the frame, followed by the filler fitting in all the horizontal arrangement. The slab must be shored in order to receive the concrete layer. Distance between joists: $40 \mathrm{~cm}$ from axis to axis. Panel slab: Reinforced concrete joists supporting a truss.

Rectangular cross section with variable base between 25 to $35 \mathrm{~cm}$ and $3 \mathrm{~cm}$ high, added to the truss. Styrofoam, can be distributed between the slabs, to reduce the amount of concrete layer. Solid Slab: Built on the construction site from wooden molds arranged horizontally. The reinforcement in metallic rebar is placed, giving more resistance to the system. After the concrete is cured, the slab is finished.
Wood frame systems for wood houses

Light Steel Framing residential buildings construction

Some types of roof tiles such as shingle tiles require an OSB deck to serve as a base on the trusses. In the case of ceramic tiles, slats are used directly on the trusses, taking care to apply an under cover blanket before slatting to ensure watertightness. Metal,

fiber cement and asphalt roofing tiles can also be used.
In the case of flat roofs the most common solution is to use a wet slab, where the water fall is solved by varying the thickness of the concrete. For flat roofs with dry slabs the simplest and most suitable solution is to use a truss system. The truss system is also used when there is a need to bridge large spans or when there are large loads to be supported by the slab. The LSF sloping roof covers use a roof truss system. Regarding the LSF roof trusses, it is necessary to ensure that the cores of the profiles used in the roofs are aligned with the uprights of the load-bearing wall panels, in order to guarantee a correct transmission of loads.
Roof structure: Technical analysis of solutions

Eco Slab: Smooth and sloping slab, the roof tiles are supported and locked juxtaposed. The slab is $7 \mathrm{~cm}$ thick supported directly on the walls. A layer of mortar with additive is placed, increasing the adhesion. Inclination of $20^{\circ}$. In the slab perimeter, metallic or wooden molds are used. One day after the molding, the slab is removed from the mould and stored for another 7 days for the curing process (sprinkling water over the slab 3 to 4 times/day).

Eco Roof: Pre-molded concrete gratings are used. The roof tiles are supported on secondary beams, located in the opposite direction to the slope, these beams are supported on main beams (anchore to the walls). Each grating forms the structure of a roof plane. Moulding on the building site with the aid of metal molds.

Steel structure: Cold formed profiles of galvanized steel. Similar to a conventional wooden structure 